\title{
Transcriptional Regulation of Metabolic and Cellular Processes in Durum Wheat (Triticum turgidum subsp. durum) in the Face of Temperature Increasing
}

\author{
Luis Abraham Chaparro-Encinas ${ }^{1,2}$, Gustavo Santoyo ${ }^{3}{ }^{\mathbb{D}}$, Juan José Peña-Cabriales ${ }^{4}$, Luciano Castro-Espinoza ${ }^{1}$, \\ Fannie Isela Parra-Cota ${ }^{5, *}$ and Sergio de los Santos-Villalobos ${ }^{1, * \text { (D }}$
}

Citation: Chaparro-Encinas, L.A.; Santoyo, G.; Peña-Cabriales, J.J.; Castro-Espinoza, L.; Parra-Cota, F.I.; Santos-Villalobos, S.d.1.

Transcriptional Regulation of Metabolic and Cellular Processes in Durum Wheat (Triticum turgidum subsp. durum) in the Face of Temperature Increasing. Plants 2021, 10, 2792. https://doi.org/10.3390/ plants10122792

Academic Editor: Daniela Trono

Received: 15 November 2021 Accepted: 7 December 2021

Published: 16 December 2021

Publisher's Note: MDPI stays neutral with regard to jurisdictional claims in published maps and institutional affiliations.

Copyright: (c) 2021 by the authors. Licensee MDPI, Basel, Switzerland. This article is an open access article distributed under the terms and conditions of the Creative Commons Attribution (CC BY) license (https:/ / creativecommons.org/licenses/by/ $4.0 /)$.
1 Instituto Tecnológico de Sonora, 5 de Febrero 818 Sur, Ciudad Obregón 85000, Sonora, Mexico; luis.chaparro15278@potros.itson.edu.mx (L.A.C.-E.); lcastro@itson.edu.mx (L.C.-E.)

2 Departamento de Fitomejoramiento, Universidad Autónoma Agraria Antonio Narro (UAAAN) Unidad Laguna, Periférico Raúl López Sánchez, Valle Verde, Torreón 27054, Coahuila, Mexico

3 Instituto de Investigaciones Químico Biológicas, Universidad Michoacana de San Nicolás de Hidalgo, Morelia 58000, Michoacán, Mexico; gustavo.santoyo@umich.mx

4 Centro de Investigación y de Estudios Avanzados, Unidad Irapuato, Libramiento Norte Carretera Irapuato León Kilómetro 9.6, Carr Panamericana Irapuato León, Irapuato 36821, Guanajuato, Mexico; juan.pena@cinvestav.mx

5 Campo Experimental Norman E. Borlaug, Instituto Nacional de Investigaciones Forestales, Agrícolas y Pecuarias (INIFAP), Norman E. Borlaug Km. 12, Valle del Yaqui, Ciudad Obregón 85000, Sonora, Mexico

* Correspondence: parra.fannie@inifap.gob.mx (F.I.P.-C.); sergio.delossantos@itson.edu.mx (S.d.1.S.-V.); Tel.: +52-(644)-410-0900 (ext. 2124) (S.d.1.S.-V.)

Abstract: The Yaqui Valley, Mexico, has been historically considered as an experimental field for semiarid regions worldwide since temperature is an important constraint affecting durum wheat cultivation. Here, we studied the transcriptional and morphometrical response of durum wheat at an increased temperature $\left(+2{ }^{\circ} \mathrm{C}\right)$ for deciphering molecular mechanisms involved in the thermal adaptation by this crop. The morphometrical assay showed a significant decrease in almost all the evaluated traits (shoot/root length, biovolume index, and dry/shoot weight) except in the dry root weight and the root:shoot ratio. At the transcriptional level, 283 differentially expressed genes (DEGs) were obtained (False Discovery Rate (FDR) $\leq 0.05$ and $\mid \log 2$ fold change $\mid \geq 1.3$ ). From these, functional annotation with MapMan4 and a gene ontology (GO) enrichment analysis with GOSeq were carried out to obtain 27 GO terms significantly enriched (overrepresented FDR $\leq 0.05$ ). Overrepresented and functionally annotated genes belonged to ontologies associated with photosynthetic acclimation, respiration, changes in carbon balance, lipid biosynthesis, the regulation of reactive oxygen species, and the acceleration of physiological progression. These findings are the first insight into the regulation of the mechanism influenced by a temperature increase in durum wheat.

Keywords: RNA-Seq; ROS; climate change; abiotic stress

\section{Introduction}

In the Yaqui Valley, the birthplace of the Green Revolution, agriculture is based on intensive practices such as monoculture, mechanization, and large-scale agrochemical applications. This region is responsible for approximately $54 \%$ of the national wheat production, mainly durum wheat (Triticum turgidum subsp. durum) [1]. However, this valley is susceptible to elevated temperatures [2,3], which puts the maintenance of food production at risk [4-6]. Climate is one of the most important determinants of durum wheat yield and accounts for $30 \%$ to $50 \%$ of the overall output variability [7]. Therefore, crop growth and yield under rising temperature scenarios are receiving increased attention. For example, the temperature effect has been calculated to reduce the durum wheat yield from $4.1 \%$ to $6.4 \%$ per Celsius degree increase [8], and a loss of yield of $24 \%$ under a growth temperature of $31^{\circ} \mathrm{C}$ in the flowering stage [7]. 
Plants respond to elevated temperatures in various ways; an increase of $2{ }^{\circ} \mathrm{C}$ to $5{ }^{\circ} \mathrm{C}$ above the optimal conditions can lead to a process known as thermomorphogenesis, which consists of changes in development and morphology influenced by a moderate increase in temperature [9]. The physiological effects of thermomorphogenesis are characterized by a fully expanded leaf structure, a larger root system, and early flowering. These are aimed at reducing the exposure of meristematic tissue to adverse conditions [10]. A temperature above this threshold of $5^{\circ} \mathrm{C}$ to $10^{\circ} \mathrm{C}$, from this point called heat stress, can lead to a decline in pollen viability, starch synthesis, and grain filling. Additionally, severe thermal stress conditions can produce seed sterility due to the sensitivity of microspore and megaspore development [11].

Durum wheat cultivars developed in tropical regions are mostly adapted to short periods of temperatures above $20-30{ }^{\circ} \mathrm{C}$; however, the temperature-influenced growth could have negative implications depending on exposure time, i.e., 5 days at temperatures above that range. Thus, an increase in temperature impacts yield-related traits, such as the thousand-kernel weight and reproductive tiller number, explaining approximately $52 \%$ of phenotypic variance [12].

In durum wheat, the stages most sensitive to heat stress are anthesis and the vegetative period; both stages are characterized by being crucial for the acquisition of nutrients (vegetative stage) and the grain filling (anthesis) [11]. Physiologically, the effect of heat stress is presented by a reduced photosynthetic rate, accelerated development, reduced flowering time, and fewer grains per spike [13]. It has been observed that the negative effects on yield may be imperceptible up to an upper limit of $31^{\circ} \mathrm{C}$ near the flowering stage. This may depend on the genotype, the availability of water, and the stage of development [14]. A temperature above $31^{\circ} \mathrm{C}$ could inhibit the transport of photoassimilates and nitrogen compounds from leaves and stems to grains [10,15].

The application of multi-omics approaches has allowed the identification of several molecular mechanisms of response to heat stress in model plants (Arabidopsis spp.), although these mechanisms are diverse and depend on specific conditions. The main temperature sensors in plants have been reported to be phytochrome B (PhyB) and phototropin, which respond to moderate changes in basal temperature and variation in red light. Once warm temperatures and red light are detected, PhyB promotes the accumulation of interactive phytochrome factors (PIF (bHLH family of transcription factors)); PIFs enhance tissue elongation through auxin signaling to result in a larger leaf area to cool the entire plant [10]. Another downstream acclimatization process involves the expression of heat shock proteins (HSP), reactive oxygen species (ROS) signaling, osmotic regulation, water transport, and cell wall modifications, among others [16].

Thus, transcriptional information suggests that temperature sensing is organ specific, with the autonomy of the root tissue triggering the cell elongation process independently of the upper sections of the plant, while the shoot responds locally and systemically [17]. This implies that the thermal detection mechanism in the roots is different (and not characterized) from PhyB and phototropin signaling because they depend on the variation of light, which is absent in the roots [17].

The above suggests that a lack in the fine thermo-sensing processes could be still unknown in the majority of crops of agricultural importance, such as durum wheat. The present study aims to analyze the physiological and transcriptional response of durum wheat seedlings to conditions of increased temperature $\left(+2{ }^{\circ} \mathrm{C}\right)$. The findings constitute the first insight at the regulation of the mechanism influenced by a temperature increase in wheat, which represents valuable information to improve our understanding of durum wheat adaptation strategies and enhance the development of new heat-tolerant varieties to help farmers in vulnerable regions cope with increasing climate risks.

\section{Results}

The morphometrical assay was carried out to compare the physiological effect of an elevated temperature $\left(+2{ }^{\circ} \mathrm{C}\right)$ vs. the optimal temperature condition for durum wheat 
production in the Yaqui Valley $\left(28^{\circ} \mathrm{C}\right)$. Thus, a negative significant (Tukey-Kramer test, $p$-value $<0.05)$ effect on root length $(-20 \%)$, dry shoot weight $(-24.5 \%)$, and biovolume index $(-28.2 \%)$ was observed by elevated temperatures. However, the root:shoot ratio showed a positive significant effect $(57.9 \%)$ under that treatment (Table 1). On the other hand, no significant differences were observed in the shoot length $(-6.7 \%)$, and dry root weight $(10.8 \%)$. However, it was also observed that the dry root weight and root:shoot ratio tended to increase in seedlings under increased temperature (Table 1).

Table 1. Morphometrical effect of durum wheat seedlings under increased temperature conditions $\left(+2{ }^{\circ} \mathrm{C}\right)$ in a growth chamber.

\begin{tabular}{cccc}
\hline Biometrical Traits & $\begin{array}{c}\text { Optimal Temperature } \\
\left(\mathbf{2 8}{ }^{\circ} \mathbf{C}\right)\end{array}$ & $\begin{array}{c}\text { Increased Temperature } \\
\left(\mathbf{3 0}{ }^{\circ} \mathbf{C}\right)\end{array}$ & Difference (\%) \\
\hline Shoot length $(\mathrm{cm})$ & $22.6 \pm 2.9$ & $21.1 \pm 4.9$ & $-6.73 \%$ \\
\hline Root length $(\mathrm{cm})$ & $16.6 \pm 3.6^{*}$ & $13.2 \pm 5.0$ & $-20.00 \%$ \\
\hline Dry shoot weight $(\mathrm{g})$ & $38.0 \pm 7.1^{*}$ & $28.7 \pm 10.3$ & $-24.50 \%$ \\
\hline Dry root weight $(\mathrm{g})$ & $52.9 \pm 12.3$ & $58.6 \pm 21.6$ & $10.80 \%$ \\
\hline Root:shoot ratio $($ dry mass, g) & $1.5 \pm 0.5$ & $2.4 \pm 1.4 *$ & $57.92 \%$ \\
\hline Biovolume index & $130.8 \pm 9.2^{*}$ & $93.9 \pm 29.2$ & $-28.20 \%$ \\
\hline
\end{tabular}

Means $(n=21) \pm$ standard deviation with an asterisk $\left(^{*}\right)$ are significantly different (increased vs. optimal temperature treatments), according to the Tukey-Kramer test $(p<0.05)$.

\subsection{Validation of RNA Extraction from Durum Wheat Seedlings, Quality, and Sequencing}

The RNA extraction from whole durum wheat seedlings (root and foliar tissue) had high-quality RNA, $92.73 \pm 24.1 \mathrm{ng} / \mu \mathrm{L}$, for seedlings growing at the optimal temperature (T_optimal), and $109.73 \pm 32.4 \mathrm{ng} / \mu \mathrm{L}$ for seedlings under increased temperature $\left(+2{ }^{\circ} \mathrm{C}\right)$ (T_heat). Additionally, all RNA Integrity Number (RIN) values were at 8.0-9.0, which indicates that isolated RNA is suitable for RNA-seq analysis [18].

Six cDNA libraries (two treatments (seedlings growing under optimal vs. increased temperature) $x$ three biological replicates) were sequenced. The high-throughput sequencing yielded 484,576,325 paired-end raw reads, distributed in 222,215,591 and 262,360,734 raw reads for T_optimal and T_heat treatments, respectively. After reads trimming/clipping, $380,019,949$ high-quality reads were obtained $(78.42 \%$ of paired-end raw reads), where $178,519,974$ corresponded to T_optimal and 201,499,975 to T_heat (Table S1). Then, 354,652,477 reads $(93.32 \%$ of total trimmed reads) were mapped to T. dicoccoides WEWSeq_v.1.0. genome $(166,012,696$ and $188,639,781$ reads belonged to T_optimal and T_heat treatment, respectively). The uniquely mapped reads were 109,451,851 reads for T_optimal and 130,998,011 reads for T_heat treatments (Table S1).

A differential expression analysis between the two studied treatments (T_optimal vs. T_heat) identified 1064 differentially expressed genes (DEGs) (False Discovery Rate $($ FDR) $\leq 0.05)$. After filtering by $\mid \log 2$ fold change $\mid \geq 1.3,283$ DEGs (78 downregulated and 205 upregulated) were obtained (Figure 1, Table S2). These 283 DEGs were used to perform the enriched gene ontology analysis. 


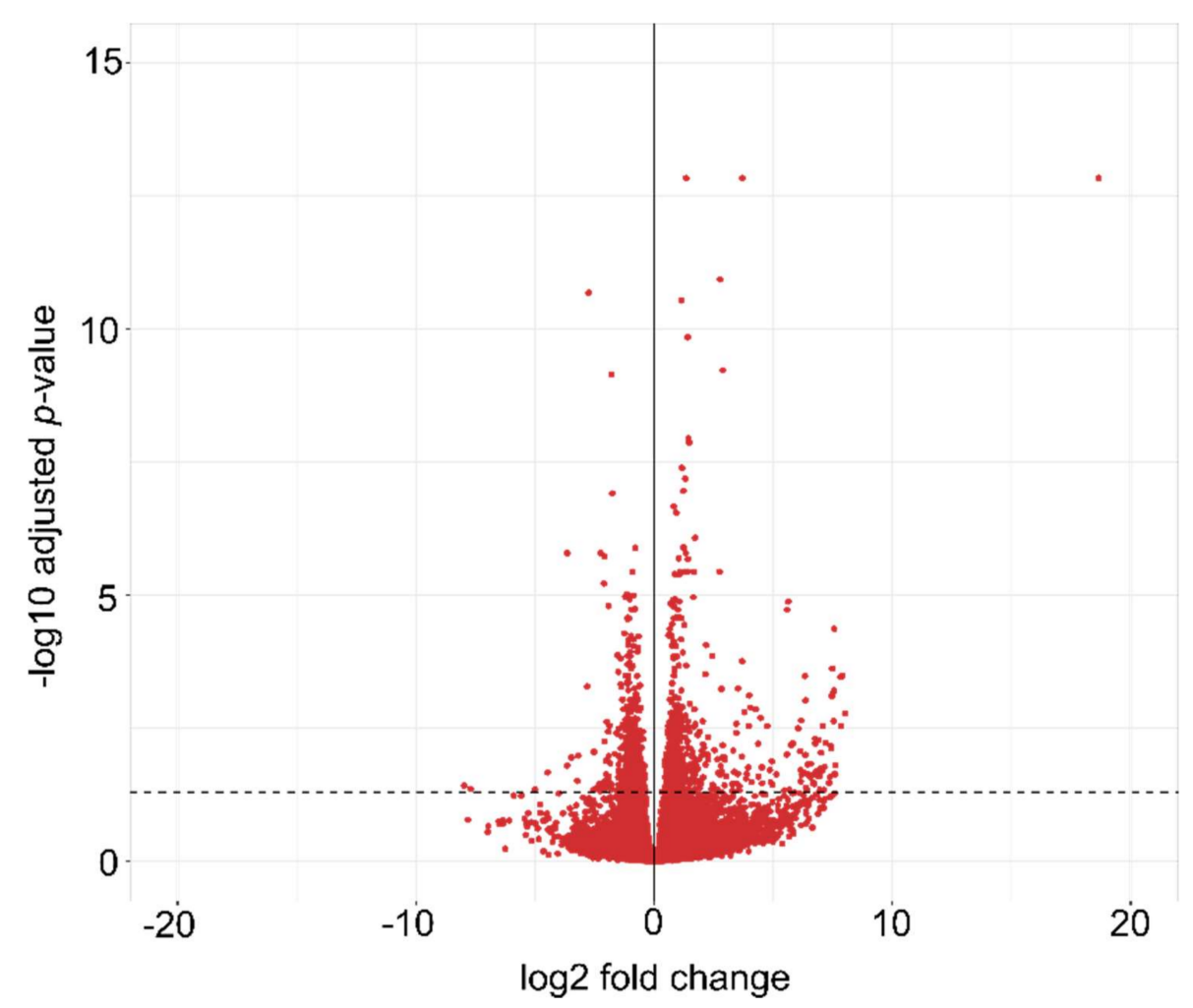

Figure 1. Volcano plot of differentially expressed genes (DEGs) in seedlings (GS21-22) under T_optimal vs. T_heat. Mean $\log 2$ fold change is plotted against the $-\log 10$ FDR adjusted $p$-values for expressed genes. Genes up of the segmented line indicate differentially expressed genes (DEGs) $($ FDR $\leq 0.05)$.

\subsection{Enriched Gene Ontology Analysis}

The sense and level of expression into functional categories by Mapman4 [19] showed that those initial 283 DEGs were classified in (i) not assigned/not annotated (106), and (ii) 20 functional categories (including not assigned/annotated) (177). The latter was composed of 47 downregulated genes (DR) and 130 upregulated genes (UR). The functional categories with the highest number of DEGs were Bin 35.1 Not assigned/annotated (74 DEGs (24 DR and 50 UR)); Bin 50 Enzyme classification (30 DEGs (9 DR and 21 UR)); Bin 18 Protein modification (14 UR); Bin 24 Solute transport (13 DEGs (2 DR and 11 UR)); Bin 15 RNA biosynthesis (13 DEGs (3 DR and 10 UR)); and Bin 5 Lipid metabolism (5 UR). Other categories were represented with five DEGs (Bin 1 Photosynthesis (3 UR); Bin 11 Phytohormone action (1 DR and 2UR); and Bin 21 Cell wall organization (2 DR and 1 UR)); and two DEGs (Bin 9 Secondary metabolism (2 UR), Bin 19 Protein homeostasis (2 UR), Bin 20 Cytoskeleton organization (1 DR and 1 UR), and Bin 27 Multi-process regulation (2 UR)) (Figure 2 and Table S3).

All obtained significant DEGs (283; FDR $\leq 0.05$ and $\mid \log 2$ fold change $\mid \geq 1.3$ ) were classified according to their relation to biological processes (BP), molecular functions $(\mathrm{MF})$, and cellular component (CC), through a gene ontology (GO) enrichment analysis performed with GOSeq [20]. Thus, 27 GO terms were significantly enriched (overrepresented FDR $\leq 0.05)(i)$, where (i) eleven belonged to $\mathrm{BP}$, from which the most represented were fatty-acyl-CoA biosynthetic process $\left(\mathrm{GO} 0046949\right.$, FDR $=2.97 \times 10^{-3}$ ), hydrogen peroxide catabolic process (GO:0042744, $\mathrm{FDR}=7.37 \times 10^{-3}$ ), oxidation-reduction process $\left(\mathrm{GO}: 0055114, \mathrm{FDR}=9.52 \times 10^{-3}\right.$ ), and inflorescence development (GO:0010229, FDR $=0.0122$ ); (ii) six to MF of which the three most represented were the theme-binding terms (GO:0020037, FDR $=8.13 \times 10^{-4}$ ), medium-chain fatty acid-CoA ligase activity (GO:0031956, FDR $=2.97 \times 10^{-3}$ ), phosphatidylethanolamine binding (GO:0008429, FDR = $\left.6.30 \times 10^{-3}\right)$, long-chain fatty acid-CoA ligase activity $\left(\mathrm{GO}: 0004467, \mathrm{FDR}=6.55 \times 10^{-3}\right)$, 
and oxidoreductase activity, acting on single donors with the incorporation of molecular oxygen (GO:0016702, FDR $=7.29 \times 10^{-3}$ ); and (iii) ten to CC, where plastoglobule (GO:0010287, FDR $=9.70 \times 10^{-4}$ ), chloroplast thylakoid membrane protein complex (GO:0098807, FDR $\left.=8.18 \times 10^{-3}\right)$, chloroplast (GO:0009507, FDR $=0.0223$ ), phragmoplast (GO:0009524, FDR = 0.0309), spindle (GO:0005819, FDR = 0.0363), and chloroplast envelope, were the most represented terms (GO:0009941, FDR $=0.0492)$ (Figure 3 and Table S4).

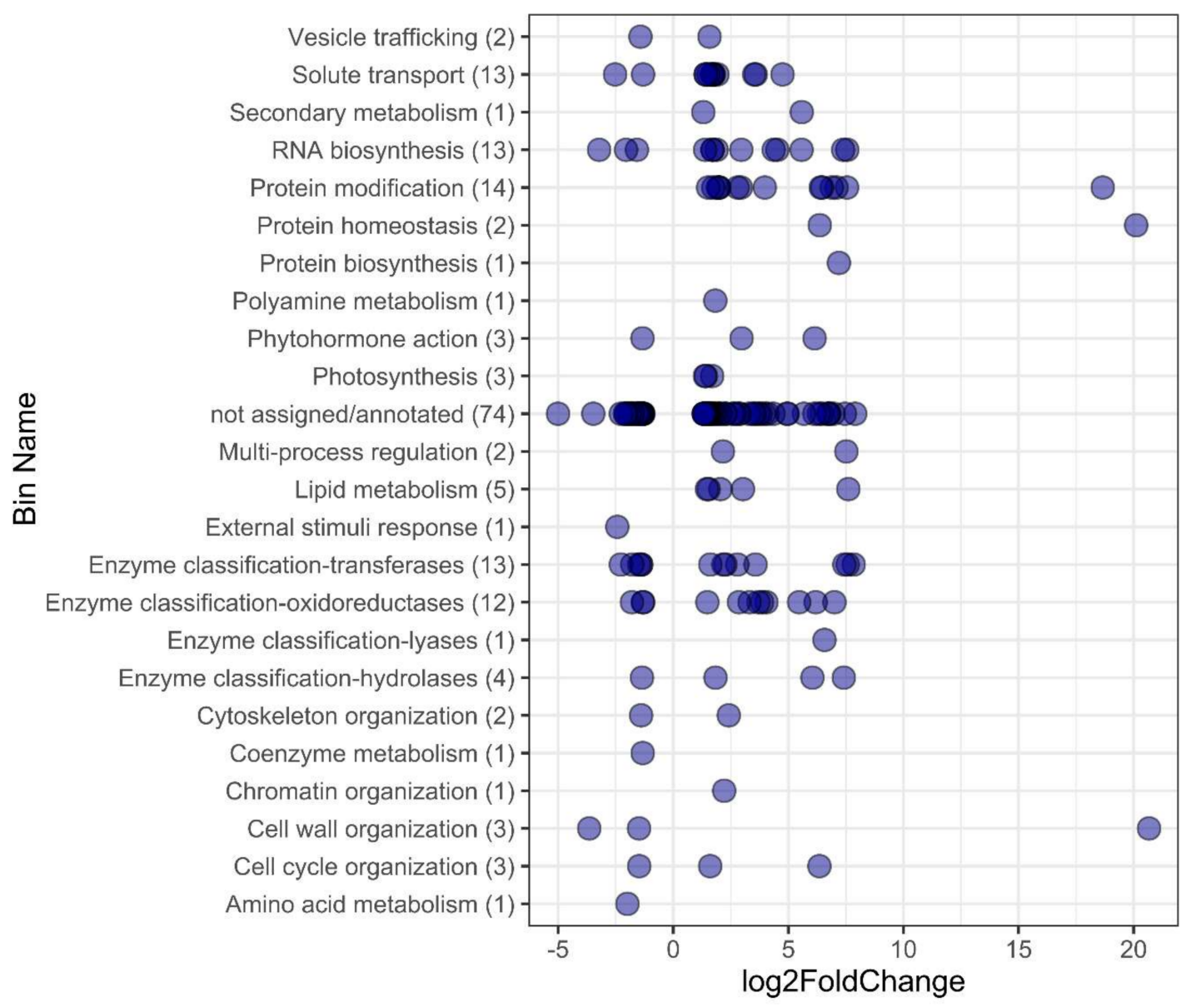

Figure 2. DEGs responsive to an elevated temperature $\left(+2{ }^{\circ} \mathrm{C}\right)$ of durum wheat seedlings, grouped into functional categories according to MapMan4 software and sense of expression (log2FoldChange). Each bubble represents a DEG. In parentheses is the number of DEGs in Bin. 


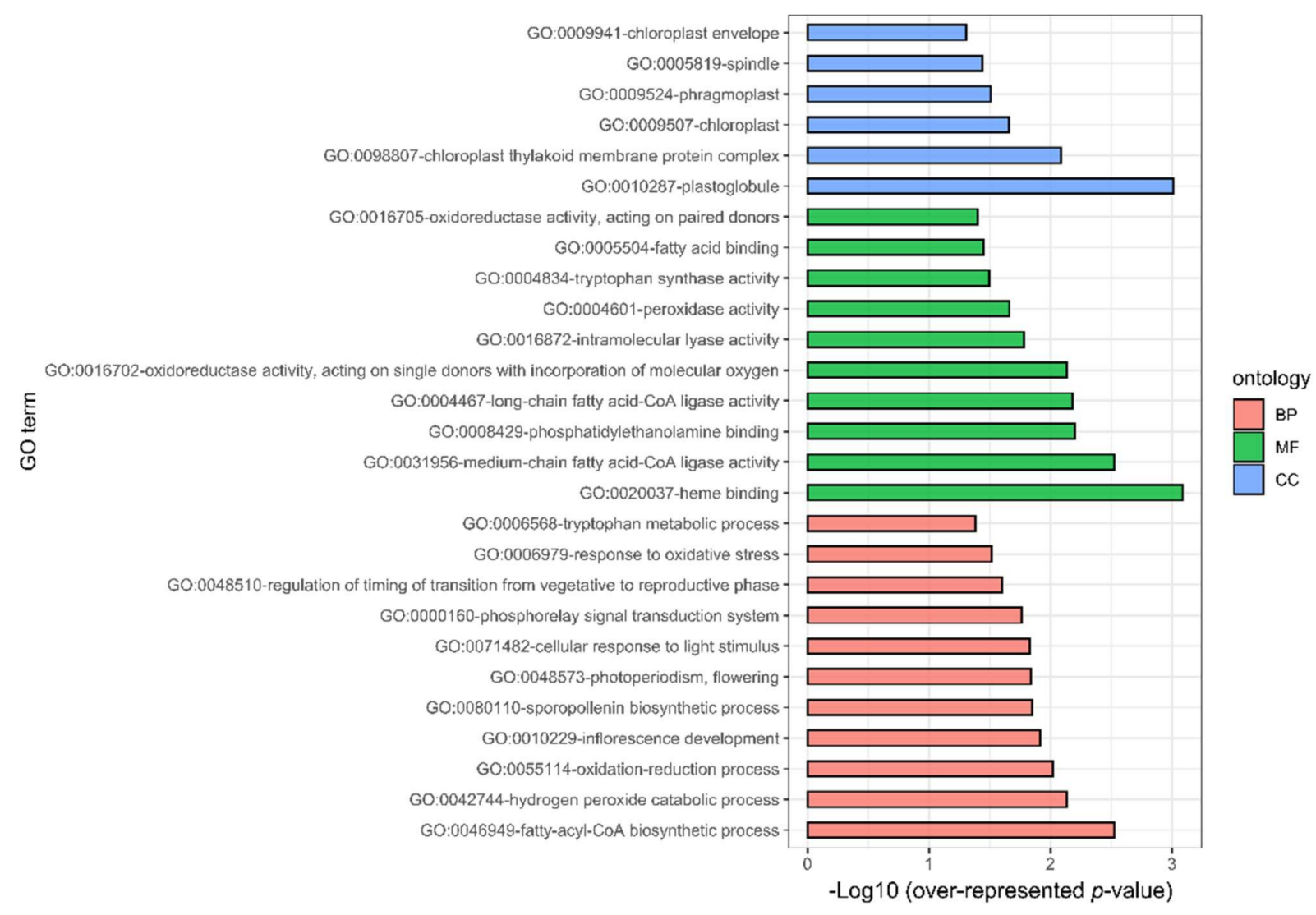

Figure 3. Gene ontology terms overrepresented (FDR $<0.05)$ in DEGs (FDR $\leq 0.05$ and $\mid \log 2$ fold change $\mid \geq 1.3)$ of durum wheat seedlings under T_optimal vs. T_heat. Bar color indicates the three categories of GO terms: Biological Processes (BP), Molecular Functions (MF), and Cellular Component (CC).

\section{Discussion}

\subsection{Morphometrical Influence of An Elevated Temperature}

In this study, we observed a significant decrease in several morphometrical traits in plants grown under an increase in temperature, i.e., root length $(-20 \%)$, dry shoot weight $(-24.5 \%)$, and biovolume index $(-28.2 \%)$ (Table 1$)$. This coincides with a significant loss of biomass in maize and broccoli seedlings at a temperature above $30{ }^{\circ} \mathrm{C}$ in the vegetative stage, previously reported by Hatfield and Prueger (2015) [21]. Such effects could be attributed to the inhibition of the transport of photoassimilates and nitrogen compounds through plant structures and protein denaturation $[10,15]$.

However, a significant increase of $57.9 \%$ in the root:shoot ratio (dry mass) was also observed; this suggests a mobilization and reprogramming of nutrients from the upper tissues to the root system, as an early response of adaptation to the increases in temperature [9,22]. Such behavior was also described by Zhang et al. (2015) [23]. in A. thaliana under heat stress of $42{ }^{\circ} \mathrm{C}$ to $45^{\circ} \mathrm{C}$, with and without a gradual acclimation process. This gradual increase in temperature maintains or increases the root growth and surviving rate. This strategy has been reported in other Arabidopsis accessions under high ambient temperatures, suggesting that root nutrient mobilization is required to move sensitive and active meristematic tissue away from the shallow soil, which absorbs heat and can promote cooling by allowing better access to water [15]. Additionally, adaptation to a high ambient temperature also involves physiological processes, such as photosynthetic acclimation, respiration, carbon balance changes, cell-wall modifications, and reactive oxygen species (ROS) regulation. 


\subsection{Acceleration of Development}

The progression of the developmental stage was evidenced by the overrepresentation of ontologies associated with this process, i.e., inflorescence development (GO:0010229 (FDR: 0.0121)), sporopollenin biosynthetic process (GO:0080110 (FDR: 0.0140)), photoperiodism and flowering (GO:0048573 (FDR: 0.0143)), regulation of timing of transition from the vegetative to reproductive phase (GO:0048510 (FDR: 0.0249)), spindle (GO:0005819 (FDR: 0.0363)), and phragmoplast (GO:0009524 (FDR: 0.0309)) (Figure 3). In durum wheat, the stages most sensitive to heat stress are anthesis and the vegetative period; both stages are characterized by being crucial for the acquisition of nutrients (vegetative stage) and the grain filling (anthesis) [11]. Physiologically, the effect of heat stress is presented by a reduced photosynthetic rate, accelerated development, reduced flowering time, and fewer grains per spike [13]. It has been observed that the negative effects on yield may be imperceptible up to an upper limit of $31^{\circ} \mathrm{C}$ near the flowering stage. This may depend on the genotype, the availability of water, and the stage of development [14]. This acceleration of plant development has been proposed as an effect of the modification of the circadian clock [24]; some of the signals regulating this mechanism include light and temperature and are associated with the compensation of plant growth in seasonal changes [25]. A study in A. thaliana reported that circadian modifications and their physiological effects, such as an accelerated change to the reproductive stage, are more significant in the increase in temperature than in the decrease [26].

\subsection{Photosynthesis and ATPase Activity}

At the transcriptional level, we highlight the DEGs that belong to the ontologies below. The genes in Bin 1 "Photosynthesis" were upregulated (UR), which included the CGL160 factor (TRIDC3BG045570, (FC: 1.689)), the light-harvesting complex LHCb1/2/3 (TRIDC5BG070090 (FC: 1.420)), and Kinesin-like protein KIN-7D (TRIDC7AG021480 (1.375)) (Figures 2 and 4). These genes are related to ATPase activity and have been reported to actively regulate photosynthetic activity under different luminosity conditions [27-30]. Previous studies in A. thaliana have described that the molecular response of the upper sections of plants to thermal increase is highly related to light sensors as such increases usually depend on the luminous intensity $[18,24]$.

On the other hand, photosynthesis activates the phosphorylation and accumulation of ATPase, which have effects on the maintenance of lipid membrane integrity. It has been reported that the overexpression of this process has positive implications for thermal tolerance in Arabidopsis [31,32]. The aforementioned is suggested by the overrepresentation of ontologies related to photosynthetic activity and thylakoid membrane to compensate the effect of increases in temperature, such as chloroplast thylakoid membrane protein complex (GO:0098807 (FDR: 0.008)), cellular response to light stimulus (GO:0071482 (FDR: 0.0148)), chloroplast (GO:0009507 (FDR: 0.0219)), chloroplast envelope (GO:0009941 (FDR: 0.0492)), and plastoglobule (GO:0010287 (FC: 0.0009)) (Figure 3). The activation of photosynthesis has been proposed as one of the first responses to thermal sensitivity and carries out the acclimatization process; this activation involves ATPase accumulation, stomatic opening, and light detection (due to the light and heat share sensing mechanism) as strategies to cope with the thermal increase [10]. It is also a requirement to accelerate physiological development to accomplish the biological cycle of plants [33]. 


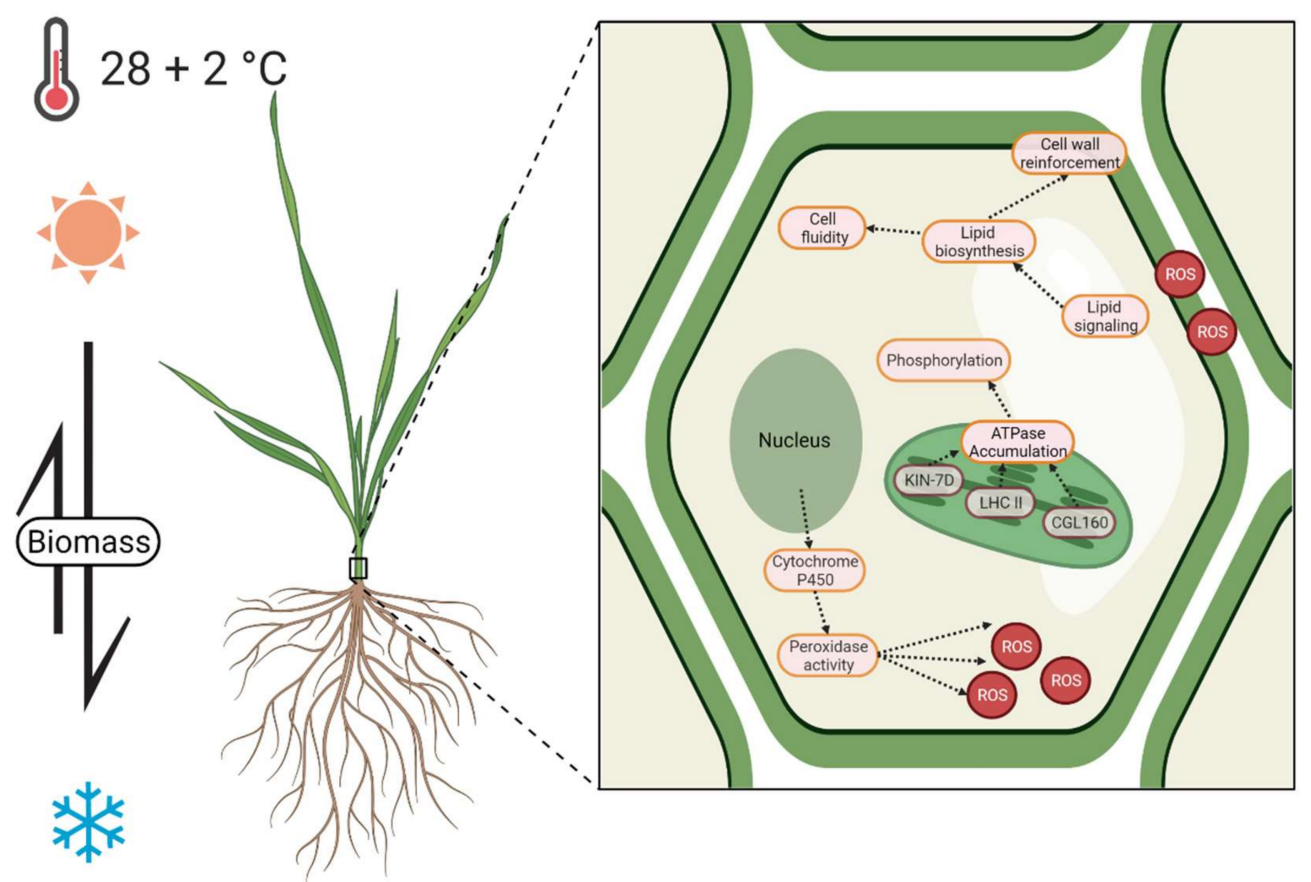

Figure 4. The first insight of the transcriptional changes of durum wheat seedlings under an increase of $+2{ }^{\circ} \mathrm{C}$ vs. optimal temperature $\left(28^{\circ} \mathrm{C}\right)$, and their possible relationship to morphometric traits. The asymmetric arrow denotes the greater transport of biomass to the roots compared to the shoots as a mechanism of protection and cooling of meristem tissue. The three main molecular acclimatization mechanisms observed are also illustrated: the promotion of photosynthesis through the accumulation of ATPases; lipid biosynthesis to (1) reinforce the cell wall; (2) adjust cell fluidity; and (3) lipid signaling; and peroxidase activity through the expression of cytochrome P450. KIN-7D, Kinesin-like protein; LHC II, light-harvesting complex II; CGL160, conserved only in the green lineage 160; ROS, reactive oxygen species. Created with BioRender.com (accessed on 28 November 2021).

\subsection{Regulation of Lipid Biosynthesis}

Another behavior observed in plants at the threshold of thermal stress is the increase in water accumulation through the synthesis of lipids and the reinforcement of the cell wall [34]. High temperatures affect the lipid composition and viscosity of the membrane, the hotter temperature made more fluid cell membranes. This phenomenon is attributed to the activation of the accumulation and remodeling of the lipid composition of the membrane (Figure 4) [35,36].

In this study, this strategy was observed by the regulation of genes in ontologies such as medium-chain fatty acid-CoA ligase activity (GO:0031956 (FDR: 0.0029)), fatty-acyl-CoA biosynthetic process (GO:0046949 (FDR: 0.0029)), and long-chain fatty acid-CoA ligase activity (GO:0004467 (FDR: 0.0065)) (Figure 3). Additionally, the classification by Mapman showed the regulation of Bin 5 Lipid metabolism composed by DEGs 3-ketoacylCoA synthase (KCS) (TRIDC5BG049870 (FC: 7.606)), 3-ketoacyl-CoA synthase (KCS) (TRIDC1AG004560 (FC: 3.028)), caleosin (TRIDC2BG056060(FC: 2.049)), isocitrate lyase (TRIDC2BG032830 (FC: 1.539)), stearoyl-ACP desaturase (TRIDC5AG021050 (FC: 1.463)); Bin 35.1 not assigned/annotated, such as fatty-acid-binding protein 1 (TRIDC2BG029870 (FC: 6.126)), UDP-glycosyltransferase 91A1 (TRIDC3BG060650 (FC: 2.259)), GDSL esterase/lipase (TRIDC3AG006590 (FC: 1.513)), GDSL esterase/lipase (TRIDC6BG067850 (FC: 1.332)), and UDP-glucosyltransferase UGT13248 (TRIDC5BG026280 (FC: 3.572)) (Figure 3). These genes have been associated with a common response to oxidative stress due damage to membranes (lipid peroxidation) [37].

\subsection{ROS Regulation and Detoxification}

A well-known effect of abiotic stress in plants, including thermal stress, is the production of ROS, which can eventually oxidize lipids, proteins, and DNA, and hence 
trigger apoptosis $[11,18,38]$. To prevent this, plants accumulate antioxidant secondary metabolites such as flavonoids, alkaloids, or terpenoids (isoprenoids), as observed in Bin 9 Secondary metabolism, i.e., aromatic L-amino acid decarboxylase (TRIDC2BG090650 (FC: 5.580)), isopentenyl diphosphate isomerase (TRIDC2BG032150 (FC: 1.305)); Bin 35.1 not assigned/annotated, as phenolic glucoside malonyltransferase 2 (TRIDC4BG008640 (FC: 1.470)); Bin 50 Enzyme classification, as flavanone 3-dioxygenase 2 (TRIDC5AG007500 (FC: 2.854)), phenolic glucoside malonyltransferase 2 (TRIDC4BG008630 (FC: 2.179)), 9-cis-epoxycarotenoid dioxygenase NCED1 (TRIDC6BG052920 (FC: 3.946)), and Geraniol 8-hydroxylase (TRIDC4BG000670 (FC: -1.307)) (Figure 2).

The main strategy that plants use to lessen the effects of oxidative stress is peroxidase activity. This process was highly represented in the ontology enrichment analysis, specifically the hydrogen peroxide catabolic process (GO:0042744 (FDR: 0.0073)), oxidation-reduction process (GO:0055114 (FDR: 0.0095)), peroxidase activity (GO:0004601 (FDR: 0.0217)), response to oxidative stress (GO:0006979 (FDR: 0.0303)), and oxidoreductase activity, acting on paired donors, with the incorporation of or reduction in molecular oxygen (GO:0016705 (FDR: 0.0395)), oxidoreductase activity, acting on single donors with the incorporation of molecular oxygen and incorporation of two atoms of oxygen (GO:0016702 (FDR: 0.0072)) (Figure 3). The DEGs related to ROS regulation and detoxification described by Mapman classification include glutathione S-transferase (TRIDC2BG032750 (FC: 1.513), Bin 18 Protein modification), peroxidase 3 (TRIDC7BG058370 (FC: 1.733), Bin 24 Solute transport), peroxidase 2 (TRIDC6AG056910 (FC: 1.522), Bin 24 Solute transport); Bin 35.1 not assigned/annotated, as peroxidase 70 (TRIDC6BG011930 (FC: 4.093)), peroxidase 2 (TRIDC2BG015880 (FC: 2.039)), and glutathione S-transferase U18 (TRIDC1BG032670 (FC: 1.338)). DEGs were previously reviewed as important elements of ROS production and detoxification process under stress conditions [38]. Furthermore, a group of cytochrome P450 family 294 genes highly expressed during chronic thermal increase was observed, including TRIDC6BG046780 ((FC: 4.521) Bin 15 RNA biosynthesis), TRIDC6BG026600 ((FC: 6.773) Bin 35.1 not assigned/annotated), TRIDC2AG019170 ((FC: 6.187) Bin 50 Enzyme classification), TRIDC2BG010230 ((FC: 5.467) Bin 50 Enzyme classification), and TRIDC2AG008470 ((FC: 3.316) Bin 50 Enzyme classification). These genes exhibit peroxidase activity under abiotic stress, such as drought, heat, oxygen and cold $[9,37,39]$ (Figures 3 and 4).

Additionally, the influence of post-transcriptional regulation through non-coding RNAs (miRNA, siRNA, lncRNA) is well known. It has been reported that the target genes of such RNAs are generally those with ontologies related to cell wall architecture, ROS regulation, and the development of the next phase, among others $[40,41]$. Similarly, epigenetic mechanisms have been found to be involved in the response to thermal stress, such as DNA methylation, histone modifications, and chromatin remodeling [42]. For the above, the struggles to fully decipher the response to thermal stress will encompass various levels of molecular organization.

\section{Materials and Methods}

\subsection{Plant Material and Growth Conditions}

Seeds of durum wheat (Triticum turgidum subsp. durum) cv. CIRNO C2008 were selected due to their wide use in the Yaqui Valley, Cd. Obregon, Sonora, México [43]. Wheat seeds were surface sterilized according to Robles Montoya et al. (2020) [44] using $0.1 \%$ sodium hypochlorite ( $30 \mathrm{~s})$, washed twice with sterilized distilled water ( $30 \mathrm{~s})$, and incubated for five days at room temperature $\left(25^{\circ} \mathrm{C}\right)$ until germination. Subsequently, the seedlings were placed in sterilized and hermetic containers (washed with ethanol at $70 \% v / v$ and treatment with ultraviolet light for $1.5 \mathrm{~h}$ ) with $130 \mathrm{~g}$ of an autoclaved substrate (30 min, $121{ }^{\circ} \mathrm{C}, 15 \mathrm{lbs}$ in three $24 \mathrm{~h}$ intervals) (soil (40\%): perlite $(60 \%)$ ) [45]. The soil used in this work was previously characterized according to Verhulst et al. (2009) [46] and Valenzuela-Aragon et al. (2019) [47]; such soil showed a high clay content (50 $\pm 10 \%)$, low organic matter content $(0.79 \pm 0.05 \%)$, and an electrical conductivity $(C E)$ value of 
$1.8 \pm 0.1 \mathrm{dS} \mathrm{m}^{-1}$, and a slightly alkaline $\mathrm{pH}$ value $(7.74 \pm 0.05)$. Additionally, this soil showed a saturation percentage of $48 \pm 1.73 \%$, CEC of $38.7 \pm 3.0 \mathrm{meq} / 100 \mathrm{~g}$, and a medium-high content of macro-elements (nitrogen (32 $\pm 8.21 \mathrm{ppm})$, phosphorus (10.4 $\pm 0.89 \mathrm{ppm})$, calcium (5746.6 $\pm 473.9 \mathrm{ppm})$, magnesium (523.3 $\pm 71.2 \mathrm{ppm})$, potassium $(613.3 \pm 30.5 \mathrm{ppm})$, sodium $(920 \pm 20 \mathrm{ppm}))$ and microelements $(\mathrm{Fe}(5.16 \pm 0.33 \mathrm{ppm})$, $\mathrm{Mn}(10.03 \pm 1.41 \mathrm{ppm}), \mathrm{Zn}(0.4 \pm 0.06 \mathrm{ppm})$, and $\mathrm{Cu}(1.0 \pm 0.03 \mathrm{ppm}))$. For irrigation purposes, to be more similar to field conditions, $70 \mathrm{~mL}$ of distilled and sterilized water was added once according to the soil moisture recommendations for the used durum wheat variety [43].

Two treatments were evaluated $(n=66$ seedlings per treatment ( 21 for morphometric assay and 15 to RNASeq (in triplicate)): (i) seedlings grown at optimal temperature conditions $\left(28^{\circ} \mathrm{C}\right.$ days and $15^{\circ} \mathrm{C}$ night) for durum wheat production in the Yaqui Valley, called "T_optimal" and (ii) seedlings grown under conditions of an elevated temperature $\left(+2{ }^{\circ} \mathrm{C}\right)$ compared to the optimal conditions $\left(30^{\circ} \mathrm{C}\right.$ days and $17^{\circ} \mathrm{C}$ night), called "T_heat". These seedlings growing in sterilized hermetic containers were placed in a growth chamber (Biobase \#BJPX-A450, Shandong, China) with the following parameters according to durum wheat requirements: photoperiod day/night 14:10 for 45 days (development stage GS21-22) $[48,49]$.

\subsection{RNA Extraction and RNA-Seq Analysis}

Fifteen seedlings were harvested per treatment (in triplicate) and frozen using liquid nitrogen. The samples were then ground in a DEPC-treated mortar and stored at $-80^{\circ} \mathrm{C}$ until processing [50]. Total RNA was isolated using a modified TRIzol ${ }^{\circledR}$ (Life Technologies; ThermoFisher, Waltham, MA, USA) method described by Chaparro-Encinas et al. 2020 [51]. The extracted total RNA was treated with DNase I (Ambion ${ }^{\mathrm{TM}}$ ) to remove genomic DNA according to the manufacturer's instructions, and subsequently, RNA Integrity Number (RIN) was obtained using a BioAnalyzer Agilent 2100 (Agilent Technologies, Santa Clara, CA, USA) to evaluate their suitability for downstream applications. The total RNA samples with RIN $>8$ were considered suitable for library preparation [18], with the TruSeq Stranded Total RNA Library Kit (Illumina, San Diego, CA, USA), and sequenced by Illumina ${ }^{\circledR}$ $2 \times 150$ en el NextSeq 500 platform $(2 \times 150 \mathrm{bp})$. A yield of approximately 85 million paired-end reads per library was obtained.

The quality of raw reads was examined using the FastQC (http:/ / www.bioinformatics. babraham.ac.uk/projects/fastqc (accessed on 1 August 2021)) tool before and after the trimming process. Raw reads were filtered with Trimmomatic 0.36 [52] by using the parameters SLIDINGWINDOW:4:30 and MINLEN:50 to deplete TruSeq adapters, lowquality reads, and short sequences $(<50 \mathrm{bp})$. Trimmed reads were mapped to the reference genome of Triticum dicoccoides "Zavitan" WEWSeq_v.1.0 [53], which is the closest ancestor of durum wheat by using default parameters in HISAT_HEAT [54]. Then, transcript abundances were counted with HTSeq-count [55] using the annotation file (Triticum_dicoccoides.WEWSeq_v.1.0.43). Thus, only unambiguously mapped reads were selected for further analysis.

Transcript abundance counts were used for gene-level differential expression analysis using the DESeq2 package [56]. A principal component analysis (PCA) was performed with DESeq2 function to reproducibility and biological variations among samples purposes. Differentially expressed genes (DEGs) were defined as those with adjusted $p$-value (False Discovery Rate, FDR) $<0.05$ and a fold change of at \pm 1.3 . Subsequently, DEGs were annotated with Mercator4 and visualized with MapMan4 [19]. Gene identifiers and Log2 fold change values of DEGs were imported into the MapMan4 framework, and transcripts were assigned into Bins.

To enriched-gene ontology analysis, all gene ontology (GO) terms associated with DEGs were extracted from the BioMart database [57]. Then, the R package GOseq [20] was used to perform a gene length bias correction with Wallenius non-central hypergeometric 
distribution. Only those GO terms with overrepresented FDR $<0.05$ were considered as significantly enriched.

\subsection{Statistical Analysis}

For durum wheat morphometric data (shoot and root length, dry weight of shoots and roots, and biovolume index (stem circumference $x$ shoot length) the statistical analysis carried out was ANOVA and Tukey-Kramer range test $(p<0.05)$ [50]. This consisted of two treatments $(n=21$ seedlings per treatment): (i) seedlings grown at optimal temperature conditions $\left(28^{\circ} \mathrm{C}\right.$ days and $15^{\circ} \mathrm{C}$ night) for durum wheat production in the Yaqui Valley and (ii) seedlings grown under conditions of an elevated temperature $\left(+2^{\circ} \mathrm{C}\right)$ compared to the optimal conditions $\left(30^{\circ} \mathrm{C}\right.$ days and $17^{\circ} \mathrm{C}$ night).

On the other hand, all statistical analyses for RNA-Seq data were carried out according to the software and parameters previously mentioned in Section 4.2. RNA extraction and RNA-Seq analysis.

\section{Conclusions}

The main observed response of durum wheat seedlings to the increase in temperature $\left(30^{\circ} \mathrm{C}\right.$ vs. $\left.28^{\circ} \mathrm{C}\right)$ was the transcriptional regulation of photosynthesis and ATPase activity; the biosynthesis and remodeling of lipid composition to reinforce the cell wall, water content, and modulate membrane fluidity; and ROS regulation as a signaling and detoxification process induced by thermal stress. These transcription patterns showed physiological signs in the acceleration of phenological progression to the reproductive stage and reprogramming of nutrient mobilization for root development, such patterns suggest a growth-to-escape strategy. These findings complement the state of the art on molecular mechanisms in plants to reduce or even tolerate the impact of climate change.

The arguments presented in this study are based on the observed transcriptomic patterns and constitute the first insights into the mechanisms regulated by the increase in temperature. Therefore, it is necessary to deepen the mechanisms proposed through multi-disciplinary approaches, including qPCR, proteomics, post-transcriptional studies (non-coding RNAs), phenomics, and epigenomics.

Supplementary Materials: The following are available online at https:/ /www.mdpi.com/article/10 $.3390 /$ plants10122792/s1, Table S1. Distribution of paired-end reads after trimming and mapping process for T_optimal and T_heat seedlings, Table S2. List of DEGs filtered by adjusted FDR $\leq 0.05$, and $\mid \log 2$ fold change $\mid \geq 1.3$, Table S3 Functional classification of DEGs [FDR $\leq 0.05$ and $\mid \log 2$ fold change $\mathrm{I} \geq 1.3$ ] by Mercator/Mapman4, Table S4. Gene ontology enrichment analysis by R package GOSeq, significantly enriched (FDR $\leq 0.05)$.

Author Contributions: L.A.C.-E., conceptualization, methodology, data curation, formal analysis, visualization, writing — original draft, and review and editing. G.S., conceptualization, methodology, and review and editing. J.J.P.-C., conceptualization, methodology, and review and editing. L.C.-E., conceptualization, methodology and review and editing. F.I.P.-C., conceptualization, methodology, and review and editing. S.d.l.S.-V., conceptualization, methodology, data curation, formal analysis, review, editing, and final approval of the manuscript. All authors have read and agreed to the published version of the manuscript.

Funding: The authors acknowledge support by the CONACyT Project 257246 "Interacción trigo $\mathrm{x}$ microorganismos promotores del crecimiento vegetal: identificando genes con potencial agrobiotecnológico"; and the PRODEP project NPTC 511-6/2020-8594. Luis Abraham Chaparro-Encinas was supported by CONACYT fellowship 292582.

Institutional Review Board Statement: Not applicable.

Informed Consent Statement: Not applicable.

Data Availability Statement: The datasets generated during and/or analyzed during the current study are available in the SRA from the NCBI repository under accession number PRJNA780180 (https:/ /www.ncbi.nlm.nih.gov/bioproject/PRJNA780180) (Accessed on 9 December 2021). 
Conflicts of Interest: The authors declare that they have no known competing financial interests or personal relationships that could have appeared to influence the work reported in this paper.

\section{References}

1. SIAP. Panorama Agroalimentario 2020, 2020th ed.; SIAP, Ed.; Secretaria de Agricultura y Desarrollo Rural: Mexico city, Mexico, 2020.

2. Matson, P.; Jewett, P. Ecosystems and land-use change in the Yaqui Valley: Does agricultural intensification spare land for nature? In Seeds of Sustainability: Lessons from the Birthplace of the Green Revolution; Island Press/Center for Resource Economics: Washington, DC, USA, 2013; pp. 47-62, ISBN 9781610911771.

3. Millar, N.; Urrea, A.; Kahmark, K.; Shcherbak, I.; Robertson, G.P.; Ortiz-Monasterio, I. Nitrous oxide (N2O) flux responds exponentially to nitrogen fertilizer in irrigated wheat in the Yaqui Valley, Mexico. Agric. Ecosyst. Environ. 2018, 261, 125-132. [CrossRef]

4. Tyczewska, A.; Woźniak, E.; Gracz, J.; Kuczyński, J.; Twardowski, T. Towards Food Security: Current State and Future Prospects of Agrobiotechnology. Trends Biotechnol. 2018, 36, 1219-1229. [CrossRef]

5. Ray, D.K.; Mueller, N.D.; West, P.C.; Foley, J.A. Yield Trends Are Insufficient to Double Global Crop Production by 2050. PLoS ONE 2013, 8, e66428. [CrossRef]

6. Rezaei, E.E.; Siebert, S.; Manderscheid, R.; Müller, J.; Mahrookashani, A.; Ehrenpfordt, B.; Haensch, J.; Weigel, H.J.; Ewert, F. Quantifying the response of wheat yields to heat stress: The role of the experimental setup. Field Crop. Res. 2018, 217, 93-103. [CrossRef]

7. Liu, B.; Asseng, S.; Müller, C.; Ewert, F.; Elliott, J.; Lobell, D.B.; Martre, P.; Ruane, A.C.; Wallach, D.; Jones, J.W.; et al. Similar estimates of temperature impacts on global wheat yield by three independent methods. Nat. Clim. Chang. 2016, 6, 1130-1136. [CrossRef]

8. Quint, M.; Delker, C.; Franklin, K.A.; Wigge, P.A.; Halliday, K.J.; Van Zanten, M. Molecular and genetic control of plant thermomorphogenesis. Nat. Plants 2016, 2, 1-9. [CrossRef] [PubMed]

9. Hayes, S.; Schachtschabel, J.; Mishkind, M.; Munnik, T.; Arisz, S.A. Hot topic: Thermosensing in plants. Plant Cell Environ. 2021, 44, 2018-2033. [CrossRef] [PubMed]

10. Sharma, D.; Singh, R.; Tiwari, R.; Kumar, R.; Gupta, V.K. Wheat Responses and Tolerance to Terminal Heat Stress: A Review. In Wheat Production in Changing Environments; Springer: Singapore, 2019; pp. 149-173, ISBN 9789811368837.

11. Balla, K.; Karsai, I.; Bónis, P.; Kiss, T.; Berki, Z.; Horváth, Á.; Mayer, M.; Bencze, S.; Veisz, O. Heat stress responses in a large set of winter wheat cultivars (Triticum aestivum L.) depend on the timing and duration of stress. PLoS ONE 2019, 14, e0222639. [CrossRef] [PubMed]

12. Eyshi Rezaei, E.; Webber, H.; Gaiser, T.; Naab, J.; Ewert, F. Heat stress in cereals: Mechanisms and modelling. Eur. J. Agron. 2015 64, 98-113. [CrossRef]

13. Ni, Z.; Li, H.; Zhao, Y.; Peng, H.; Hu, Z.; Xin, M.; Sun, Q. Genetic improvement of heat tolerance in wheat: Recent progress in understanding the underlying molecular mechanisms. Crop J. 2018, 6, 32-41. [CrossRef]

14. Liu, B.; Asseng, S.; Liu, L.; Tang, L.; Cao, W.; Zhu, Y. Testing the responses of four wheat crop models to heat stress at anthesis and grain filling. Glob. Chang. Biol. 2016, 22, 1890-1903. [CrossRef]

15. Zhang, H.; Zhao, Y.; Zhu, J.K. Thriving under Stress: How Plants Balance Growth and the Stress Response. Dev. Cell 2020, 55, 529-543. [CrossRef]

16. Bellstaedt, J.; Trenner, J.; Lippmann, R.; Poeschl, Y.; Zhang, X.; Friml, J.; Quint, M.; Delkera, C. A mobile auxin signal connects temperature sensing in cotyledons with growth responses in hypocotyls. Plant Physiol. 2019, 180, 757-766. [CrossRef] [PubMed]

17. Lamers, J.; van der Meer, T.; Testerink, C. How Plants Sense and Respond to Stressful Environments. Plant Physiol. 2020, 182, 1624-1635. [CrossRef]

18. Schroeder, A.; Mueller, O.; Stocker, S.; Salowsky, R.; Leiber, M.; Gassmann, M.; Lightfoot, S.; Menzel, W.; Granzow, M.; Ragg, T. The RIN: An RNA integrity number for assigning integrity values to RNA measurements. BMC Mol. Biol. 2006, 7, 1-14. [CrossRef] [PubMed]

19. Schwacke, R.; Ponce-Soto, G.Y.; Krause, K.; Bolger, A.M.; Arsova, B.; Hallab, A.; Gruden, K.; Stitt, M.; Bolger, M.E.; Usadel, B. MapMan4: A Refined Protein Classification and Annotation Framework Applicable to Multi-Omics Data Analysis. Mol. Plant 2019, 12, 879-892. [CrossRef]

20. Young, M.D.; Wakefield, M.J.; Smyth, G.K.; Oshlack, A. Gene ontology analysis for RNA-seq: Accounting for selection bias GOseq GOseq is a method for GO analysis of RNA-seq data that takes into account the length bias inherent in RNA-seq. Genome Biol. 2010, 11, R14. [CrossRef]

21. Hatfield, J.L.; Prueger, J.H. Temperature extremes: Effect on plant growth and development. Weather Clim. Extrem. 2015, 10, 4-10. [CrossRef]

22. Mašková, T.; Herben, T. Root:shoot ratio in developing seedlings: How seedlings change their allocation in response to seed mass and ambient nutrient supply. Ecol. Evol. 2018, 8, 7143-7150. [CrossRef]

23. Zhang, N.; Belsterling, B.; Raszewski, J.; Tonsor, S.J. Natural populations of Arabidopsis thaliana differ in seedling responses to high temperature stress. AoB Plants 2015, 7, plv101. [CrossRef]

24. Webb, A.A.R.; Seki, M.; Satake, A.; Caldana, C. Continuous dynamic adjustment of the plant circadian oscillator. Nat. Commun. 2019, 10, 550. [CrossRef] [PubMed] 
25. Gil, K.; Park, C. Thermal adaptation and plasticity of the plant circadian clock. New Phytol. 2019, 221, 1215-1229. [CrossRef]

26. Masuda, K.; Yamada, T.; Kagawa, Y.; Fukuda, H. Time Lag Between Light and Heat Diurnal Cycles Modulates CIRCADIAN CLOCK ASSOCIATION 1 Rhythm and Growth in Arabidopsis thaliana. Front. Plant Sci. 2021, 11, 1-10. [CrossRef] [PubMed]

27. Fristedt, R.; Martins, N.F.; Strenkert, D.; Clarke, C.A.; Suchoszek, M.; Thiele, W.; Schöttler, M.A.; Merchant, S.S. The thylakoid membrane protein CGL160 supports CF1CF0 ATP synthase accumulation in Arabidopsis thaliana. PLoS ONE 2015, 10, e0121658. [CrossRef] [PubMed]

28. Pietrzykowska, M.; Suorsa, M.; Semchonok, D.A.; Tikkanen, M.; Boekema, E.J.; Aro, E.; Jansson, S. The Light-Harvesting Chlorophyll a/b Binding Proteins Lhcb1 and Lhcb2 Play Complementary Roles during State Transitions in Arabidopsis. Plant Cell 2014, 26, 3646-3660. [CrossRef] [PubMed]

29. Li, J.; Xu, Y.; Chong, K. The novel functions of kinesin motor proteins in plants. Protoplasma 2012, 249, 95-100. [CrossRef]

30. Grahl, S.; Reiter, B.; Gügel, I.L.L.; Vamvaka, E.; Gandini, C.; Jahns, P.; Soll, J.; Leister, D.; Rühle, T. The Arabidopsis Protein CGLD11 Is Required for Chloroplast ATP Synthase Accumulation. Mol. Plant 2016, 9, 885-899. [CrossRef] [PubMed]

31. Niu, Y.; Qian, D.; Liu, B.; Ma, J.; Wan, D.; Wang, X.; He, W.; Xiang, Y. ALA6, a P4-type ATPase, is involved in heat stress responses in Arabidopsis thaliana. Front. Plant Sci. 2017, 8, 1-13. [CrossRef]

32. Okumura, M.; Inoue, S.I.; Kuwata, K.; Kinoshita, T. Photosynthesis activates plasma membrane H+-ATPase via sugar accumulation. Plant Physiol. 2016, 171, 580-589. [CrossRef]

33. Estravis-Barcala, M.; Mattera, M.G.; Soliani, C.; Bellora, N.; Opgenoorth, L.; Heer, K.; Arana, M.V. Molecular bases of responses to abiotic stress in trees. J. Exp. Bot. 2020, 71, 3765-3779. [CrossRef]

34. Liu, Z.; Xin, M.; Qin, J.; Peng, H.; Ni, Z.; Yao, Y.; Sun, Q. Temporal transcriptome profiling reveals expression partitioning of homeologous genes contributing to heat and drought acclimation in wheat (Triticum aestivum L.). BMC Plant Biol. 2015, 15, 1-20. [CrossRef]

35. Mueller, S.P.; Unger, M.; Guender, L.; Fekete, A.; Mueller, M.J. Phospholipid: Diacylglycerol acyltransferase-mediated triacylglyerol synthesis augments basal thermotolerance. Plant Physiol. 2017, 175, 486-497. [CrossRef]

36. Demski, K.; Łosiewska, A.; Jasieniecka-Gazarkiewicz, K.; Klińska, S.; Banaś, A. Phospholipid:Diacylglycerol Acyltransferase1 Overexpression Delays Senescence and Enhances Post-heat and Cold Exposure Fitness. Front. Plant Sci. 2020, 11, 1-14. [CrossRef]

37. Choudhury, F.K.; Rivero, R.M.; Blumwald, E.; Mittler, R. Reactive oxygen species, abiotic stress and stress combination. Plant J. 2017, 90, 856-867. [CrossRef] [PubMed]

38. Farooq, M.A.; Niazi, A.K.; Akhtar, J.; Farooq, M.; Souri, Z.; Karimi, N.; Rengel, Z. Acquiring control: The evolution of ROSInduced oxidative stress and redox signaling pathways in plant stress responses. Plant Physiol. Biochem. 2019, 141, 353-369. [CrossRef] [PubMed]

39. Xu, J.; Wang, X.; Guo, W. The cytochrome P450 superfamily: Key players in plant development and defense. J. Integr. Agric. 2015, 14, 1673-1686. [CrossRef]

40. Ravichandran, S.; Ragupathy, R.; Edwards, T.; Domaratzki, M.; Cloutier, S. Microrna-guided regulation of heat stress response in wheat. BMC Genom. 2019, 20, 1-16. [CrossRef]

41. Sihag, P.; Sagwal, V.; Kumar, A.; Balyan, P.; Mir, R.R.; Dhankher, O.P.; Kumar, U. Discovery of miRNAs and Development of Heat-Responsive miRNA-SSR Markers for Characterization of Wheat Germplasm for Terminal Heat Tolerance Breeding. Front. Genet. 2021, 12, 1-12. [CrossRef]

42. Zhao, J.; Lu, Z.; Wang, L.; Jin, B. Plant responses to heat stress: Physiology, transcription, noncoding rnas, and epigenetics. Int. J. Mol. Sci. 2021, 22, 117. [CrossRef]

43. Figueroa López, P.; Félix Fuentes, J.; Fuentes Dávila, G.; Valenzuela Herrera, V.; Chávez Villalba, G.; Mendoza Lugo, J. Cirno c2008, nueva variedad de trigo cristalino con alto rendimiento potencial para el estado de Sonora. Rev. Mex. Ciencias Agrícolas 2010, 1, 745-749.

44. Robles Montoya, R.I.; Chaparro Encinas, L.A.; Parra Cota, F.I.; De los Santos Villalobos, S. Mejorando rasgos biométricos de plántulas de trigo con la inoculación de un consorcio nativo de Bacillus. Rev. Mex. Ciencias Agrícolas 2020, 11, 229-235. [CrossRef]

45. Lees, K.; Fitzsimons, M.; Snape, J.; Tappin, A.; Comber, S. Soil sterilisation methods for use in OECD 106: How effective are they? Chemosphere 2018, 209, 61-67. [CrossRef] [PubMed]

46. Verhulst, N.; Deckers, J.; Govaerts, B. Classification of the Soil at CIMMYT 's Experimental Station in the Yaqui Valley Near Ciudad Obregón, Sonora, México; CIMMYT Report; CIMMYT: Ciudad de Mexico, Mexico, 2009.

47. Valenzuela-Aragon, B.; Parra-Cota, F.I.; Santoyo, G.; Arellano-Wattenbarger, G.L.; de los Santos-Villalobos, S. Plant-assisted selection: A promising alternative for in vivo identification of wheat (Triticum turgidum L. subsp. Durum) growth promoting bacteria. Plant Soil 2019, 435, 367-384. [CrossRef]

48. Zadoks, J.C.; Chang, T.T.; Konzak, C.F. A Decimal Code for the Growth Stages of Cereals. Weed Res. 1974, 14, 415-421. [CrossRef]

49. Rojas Padilla, J.; Chaparro Encinas, L.A.; Robles Montoya, R.I.; De los Santos Villalobos, S. Promoción de crecimiento en trigo (Triticum turgidum L. subsp. durum) por la co-inoculación de cepas nativas de Bacillus aisladas del Valle del Yaqui, México. Nov. Sci. 2020, 12. [CrossRef]

50. Tüzmen, S.; Baskin, Y.; Nursal, A.F.; Eraslan, S.; Esemen, Y.; Çalibas, G.; Demir, A.B.; Abbasoglu, D.; Hizel, C. Techniques for nucleic acid engineering: The foundation of gene manipulation. In Omics Technologies and Bio-Engineering: Towards Improving Quality of Life; Elsevier: Belo Horizonte, Brazil, 2018; Volume 1, pp. 247-315, ISBN 9780128047491. 
51. Chaparro-Encinas, L.A.; Arellano-Wattenbarger, G.L.; Parra-Cota, F.I.; de los Santos-Villalobos, S. A modified CTAB and Trizol ${ }^{\circledR}$ protocol for high-quality RNA extraction from whole wheat seedlings, including rhizosphere. Cereal Res. Commun. 2020, 48, 275-282. [CrossRef]

52. Bolger, A.M.; Lohse, M.; Usadel, B. Trimmomatic: A flexible trimmer for Illumina sequence data. Bioinformatics 2014, 30, 2114-2120. [CrossRef]

53. Avni, R.; Nave, M.; Barad, O.; Baruch, K.; Twardziok, S.O.; Gundlach, H.; Hale, I.; Mascher, M.; Spannagl, M.; Wiebe, K.; et al Wild emmer genome architecture and diversity elucidate wheat evolution and domestication. Science 2017, 357, 93-97. [CrossRef]

54. Kim, D.; Langmead, B.; Salzberg, S.L. HISAT: A fast spliced aligner with low memory requirements. Nat. Methods 2015, 12, 357-360. [CrossRef]

55. Anders, S.; Pyl, P.T.; Huber, W. HTSeq-A Python framework to work with high-throughput sequencing data. Bioinformatics 2015, 31, 166-169. [CrossRef]

56. Love, M.I.; Huber, W.; Anders, S. Moderated estimation of fold change and dispersion for RNA-seq data with DESeq2. Genome Biol. 2014, 15, 550. [CrossRef] [PubMed]

57. Smedley, D.; Haider, S.; Durinck, S.; Pandini, L.; Provero, P.; Allen, J.; Arnaiz, O.; Awedh, M.H.; Baldock, R.; Barbiera, G.; et al. The BioMart community portal: An innovative alternative to large, centralized data repositories. Nucleic Acids Res. 2015, 43, W589-W598. [CrossRef] [PubMed] 